\title{
透明な細動脈膜モデルの製作方法の提案
}

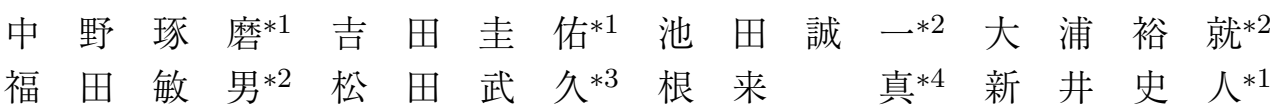

\section{Proposal on Fabrication Method of Transparent Arteriole Membrane Models}

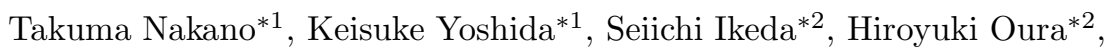
Toshio Fukuda*2, Takehisa Matsuda*3, Makoto Negoro*4 and Fumihito Arai*1

\begin{abstract}
We fabricated a transparent arteriole membrane model by grayscale lithography. Employed fabrication method was using a wax and polyvinyl alcohol mixture as a novel molding material for fabricating a sacrificial model. Our objective was to complement previous surgical simulators for practice and rehearsal of medical treatments. Since block vessel models cannot recreate the moderate compliance that is generally seen in real blood vessels, we proposed a method for fabricating a transparent membranous arteriole model having a circular cross-section less than 500 [ $\mu \mathrm{m}$ ] in diameter. Here, we describe the fabrication of our model and the evaluation results of our new molding material.
\end{abstract}

Key Words: Photolithography, Blood Vessel Model, Surgical Simulator

\section{1. 緒 \\ 言}

再生医療分野において，人工心臟や人工関節，人工血管といっ た人工材料を用いた様々な工学的アプローチの研究が進められ ている [1] [2]. 特に人工血管に関する研究では, 血管再生を目 的とした血管内皮細胞の行動形態観察や細胞接着足場に関する 研究やカテーテル手術のリハーサル，新人医師の技術習熟や新 しい手術方式開発のための血管シミュレータに関する研究が盛 んに行われている. 現在, 我々は $\mathrm{CT} / \mathrm{MRI}$ の個人情報に基づ き, 積層造形機を用い三次元 WAX モデルを作製し, デイップ コーティングと選択的溶解でシリコーン樹脂製の血管モデルを 各部分ごとに作製し，それぞれの血管モデルを接続することで 血管シミュレータを作製している [3] [4]（Fig. 1).

しかし，現在の積層造形機によるWAX モデルを用いる作製 方法では, WAX が脆性材料であるため内径 $500[\mu \mathrm{m}]$ 以下の血 管モデルの作製は困難であり, 人間の血流環境を完全に再現で きていない，また，脳底血管のような内径 $100[\mu \mathrm{m}]$ 程度の非 常に細い血管内でも血管疾患が起こることが確認されているが,

\footnotetext{
原稿受付 2008 年 12 月 25 日

$* 1$ 東北大学

$* 2$ 名古屋大学

$* 3$ 金沢工業大学

$* 4$ 藤田保健衛生大学

${ }^{* 1}$ Tohoku University

${ }^{* 2}$ Nagoya University

${ }^{* 3}$ Kanazawa Institute of Technology

${ }^{* 4}$ Fujita Health University

本論文は学術性で評価されました。
}

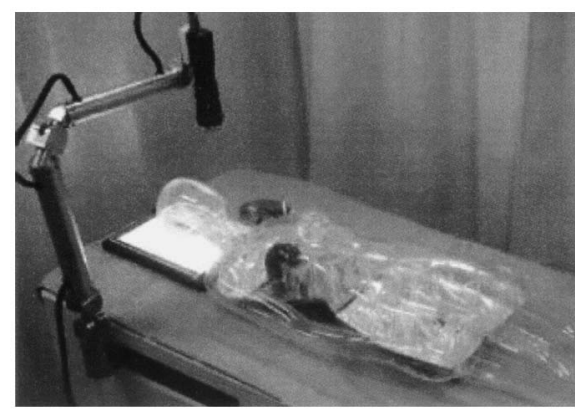

Fig. 1 Surgical simulator for endovascular neurosugery, which allows evaluating stress condition on arterial structure applied with surgical operation and blood streaming, using photoelastic modality

従来の血管シミュレータでは内径 $500[\mu \mathrm{m}]$ 以下の血管内で起 こる血管疾患の治療を対象としたリハーサルを行うことができ ない.

この従来の血管シミュレータの欠点を補うために, 我々は従来 の血管シミュレータに組み込むことが可能な内径 10〜 500 [ $\mu \mathrm{m}]$ の細動脈・毛細血管といった極細径の血管を模擬したマイクロ流 路が必要であると考えている. マイクロ流路の作製方法には様々 な方法が考えられ，代表的なものを挙げると，切削や鋳造，研磨 に代表される機械加工技術と，フォトリソグラフィーや LIGA プロセス，マイクロ光造形に代表される MEMS 加工技術があ る. 機械加工は最小分解能が $10[\mu \mathrm{m}]$ 程度であり, また複雑形 状の加工が非常に難しく, 現在も研究が進められている段階で 
ある. 一方, MEMS 加工技術はパソコンの IC やセンサとして 用いるカンチレバー, 小型発電装置など様々な微小装置を作製 するのに用いられる加工法である。特にフォトリソグラフィー プロセスはこれらの装置の作製の中で，基盤となっている技術 であり, 最小分解能 $1[\mu \mathrm{m}]$ 程度の加工が可能である. この利点 から, 今回作製する細動脈・毛細血管モデルと称するマイクロ 流路はフォトリソグラフィーにより作製する。血管モデルは実 際の血管の断面形状を模し，円形または楕円形で作製する必要 がある. しかし，フォトリソグラフィーで円形断面のチューブ 状のマイクロ流路を作製することは非常に難しく，これまでに 作製した例は報告されていない. マイクロ流路の従来研究には, 文献 [5]〜 [7] のように半球面のフォトレジストパターンや光硬化 性樹脂製の型を用いて，流路を作製した例があるが，断面が半 円形であるため，血管モデルとして用いることはできない．し たがって，円形断面を有する細動脈・毛細血管モデルを作製す るには新しい作製コンセプトが必要であると考え, 私達はフォ トリソグラフィーと PDMS (poly (dimethylsiloxane)) を用い て血管モデルの開発を行ってきた。透明材料である PDMS を 使用するのは，作製すべき血管モデルは手術リハーサルを行う ためのものであり, 使用者に手術器具等の影響を視覚的に教示 する必要があるからである。本稿では，これまで私達が作製し てきたブロック型細動脈・毛細血管モデルを説明し，ブロック 型モデルの問題点を挙げ, この問題解決のために今回提案し試 作した膜型細動脈モデルに関して説明する。

\section{2. ブロック型細動脈・毛細血管モデルの問題点}

内径 10〜 500 $[\mu \mathrm{m}]$ のブロック型細動脈・毛細血管モデルは, 実際の血管構造を模擬した. 円形断面血管モデルは Fig. 2 のよ うな設計に基づき，フォトリソグラフィーで作製してきた $[8]$. Fig. 3 に示すように，円形断面モデル作製に用いるフォトリソ グラフィープロセスには, オーバー露光法, リフロー法, グレ イスケールリソグラフィーの三種類がある. これらの露光法そ れぞれに作製できるモデル径の限界が存在するので，目的とす る作製モデル径によって適切な方法を使い分ける必要がある. 例えば, 内径 10〜 $20[\mu \mathrm{m}]$ の毛細血管モデルはオーバー露光法 で, 内径 $20 \sim 100[\mu \mathrm{m}]$ の細動脈モデルはリフロー法で, 内径 100〜 $500[\mu \mathrm{m}]$ の細動脈モデルはグレイスケールリソグラフィー によって作製することが可能である。細動脈・毛細血管モデル は, フォトリソグラフィーで作製したモデルパターンを PDMS に転写し，プラズマ親水化後，組み立てアライメントし，120～

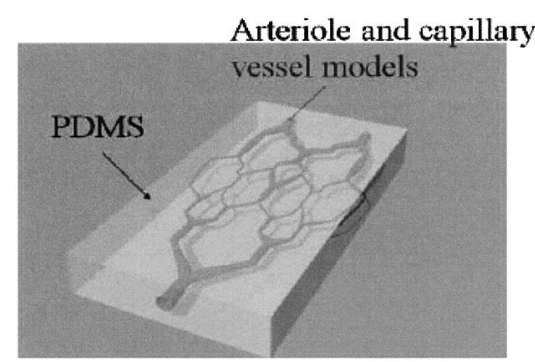

Fig. 2 Designed arteriole and capillary vessel model $145^{\circ} \mathrm{C}$ に加熱することでボンディングして作製することができ る (Fig. 4).これらの露光法でこれまでに作製してきた細動脈・ 毛細血管モデルを Fig. 5 に示す. しかし, これらのモデルはブ ロック型の血管モデルであり，本物の血管のヤング率などのコ ンプライアンスを再現することができない [9]〜 [12]. この問題 を解決するために，細動脈・毛細血管モデルを膜モデルで作製 する必要があるが, 従来の作製方法 (積層造形法, layer stack modeling machine) では WAX が脆性材料であるため犠牲モ デルを作製することが難しかった。

今回, この問題の解決のために, 透明な細動脈膜モデルを作製 する新しい方法を提案する. WAX にポリマーであるポリビニル アルコール（PVA）を混ぜることで脆性性質を低下させ，犠牲 モデルを作製し，ディップコーティングによって細動脈膜モデル を作製した。今回提案する血管シミュレータ用の内径 $500[\mu \mathrm{m}]$ 以下の膜型血管モデルを作製する利点は，（1）脳底血管のよう な内径 $100[\mu \mathrm{m}]$ 程度の血管内で起こる血管疾患を治療対象に できるようになること，（2）流体力学的に従来よりも血流環境 の再現性が向上することが挙げられる．今回は試作段階である ため，内径 $500[\mu \mathrm{m}]$ の犠牲モデルを作製し，シリコーン樹脂を ディップコートすることで細動脈膜モデルの試作を行った。作 製するモデルは，内径 $500[\mu \mathrm{m}]$, 長さ $4[\mathrm{~mm}]$, 真円度 $80 \%$ 以 上を目標值とする。 また，犠牲モデル作製には，WAX と PVA の混合材料を用いることが非常に重要になるので，本混合材料 の評価も行った。

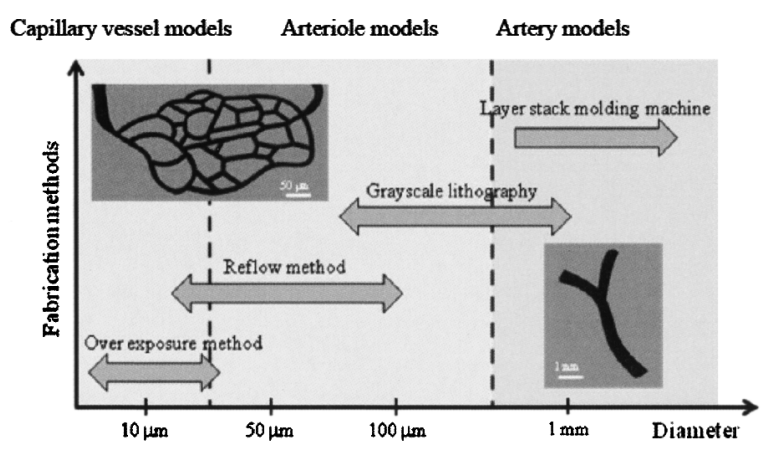

Fig. 3 Concept of fabrication methods for multi scale blood vessel models

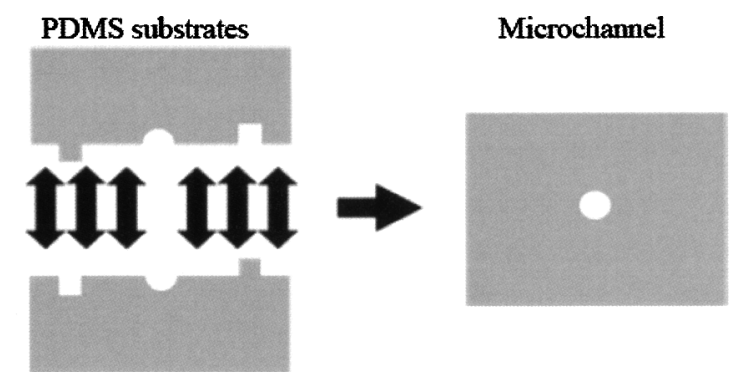

Plasma treatment Heating process

Fig. 4 Concept behind the making of our capillary vessel model. After plasma treatment, we aligned two patterned PDMS substrates and bonded them to complete blood vessel model 

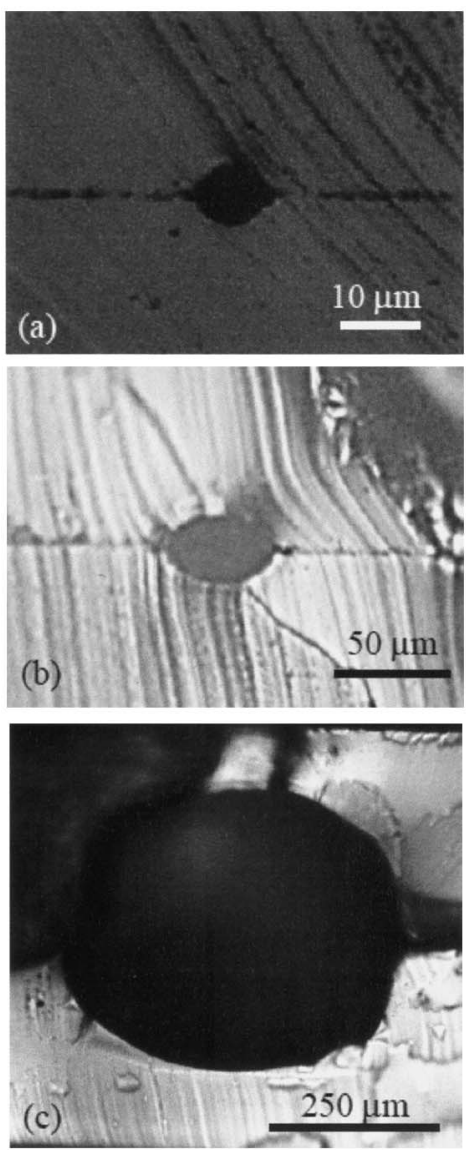

Fig. 5 Cross sections of fabricated model. (a) $\Phi 10[\mu \mathrm{m}]$ microchannel (b) $\Phi 50[\mu \mathrm{m}]$ microchannel (c) $\Phi 500[\mu \mathrm{m}]$ microchannel

\section{3. $\mathrm{WAX}+\mathrm{PVA}$ 混合材料の評価}

この膜モデルの作製において, WAX +PVA 混合材料で犠牲 モデルを作製することが内径 $500[\mu \mathrm{m}]$ 以下の膜モデルを作製す るのに非常に重要な役割を果たしている.WAX のみで作製する には, 周辺温度 $150^{\circ} \mathrm{C}$ 程度の管理が必要であり, また, 伸び率 が $6 \%$ 程度しかなく脆い材料であるため, 壊れやすく, 今回の犠 牲モデルの作製には適さない. PVAのみで作製すると, ヤング 率が 10 [MPa] 程度であるため, 曲げ剛性 EI（E：ヤング率, I ： 断面二次モーメント）が小さくなり, デイップコート時に自重で 形状の変形が起こってしまう，そこで，WAX と PVAを混合し て犠牲モデルを作製する手法を考案した，本混合材料の特性と してはWAX と PVA の双方の特性を併せ持っていることが容 易に予想できるが, 今回, WAX と PVA の混合比によってどの ような特性の変化があるのか評価を行った，試験片作製に用いる WAX (InduraCast ${ }^{\mathrm{TM}}$, SolidScape) と PVA (JP18, 日本酢 ビ・ポバール）は, 共溶媒 (エタノール, DI 水の混合比 $1: 1$ 溶液) $1[\mathrm{ml}]$ を用いて, $100^{\circ} \mathrm{C}$ で加熱溶融および攪拌することで混合し た. 混合比（質量比）は WAX : PVA = $1: 0,4: 1,3: 2,2: 3$, $1: 4,0: 1$ で作製した。評価した特性は機械的特性としてヤン グ率 (縦弾性係数), 化学的特性として溶液に対する溶解度の評 価を行った。
Table 1 Experimental rigidity

\begin{tabular}{|c|c|}
\hline $\begin{array}{c}\text { PVA:WAX } \\
\text { ratio [\%] }\end{array}$ & $\begin{array}{c}\text { Young's modulus } \\
\text { [MPa] }\end{array}$ \\
\hline $1: 0$ & 9.57 \\
\hline $4: 1$ & 9.69 \\
\hline $3: 2$ & 8.78 \\
\hline $2: 3$ & 15.7 \\
\hline $1: 4$ & 22.8 \\
\hline $0: 1$ & 20.6 \\
\hline
\end{tabular}

Table 2 Experimental brittleness and ductibility

\begin{tabular}{|c|c|}
\hline $\begin{array}{c}\text { PVA:WAX } \\
\text { ratio [\%] }\end{array}$ & $\begin{array}{c}\text { Extension } \\
{[\%]}\end{array}$ \\
\hline $1: 0$ & 75 \\
\hline $4: 1$ & 75 \\
\hline $3: 2$ & 75 \\
\hline $2: 3$ & 44 \\
\hline $1: 4$ & 4.0 \\
\hline $0: 1$ & 6.0 \\
\hline
\end{tabular}

\section{1 機械的特性（ヤング率）の評価}

ヤング率測定には引張り試験機を用いた，使用する試験片は， $50 \times 10 \times 2[\mathrm{~mm}] （$ 長さ $\times$ 幅 $\times$ 厚さ）で作製した。測定結果は， 荷重-変位曲線で出力されるので, このデータからグラフの初 期立ち上がりを読み取ってヤング率を計算し，測定結果とした。 また試験は, 引っ張り速度 $5\left[\mathrm{~mm} / \mathrm{min}\right.$.], 温度 $25^{\circ} \mathrm{C}$ の環境下 で, 各混合率試験片に対し 3 回行った。測定結果から算出した ヤング率を Table 1 に示す．また，材料の脆性・延性を表す指 標として伸び (Extension) がある. 本実験から得られた伸びを Table 2 に示す. PVA のヤング率が $9.57[\mathrm{MPa}]$ であるのに対 し, WAX のヤング率は $20.6[\mathrm{MPa}]$ であった，混合材料試験片 はWAX の割合が増えるほどヤング率が大きくなっていく傾向 が確認された，また，PVAの割合が増えるにつれて，伸びが大 きくなっていくことを確認した，したがって，混合比によって， WAX と PVA の機械的性質を制御できることが分かった．この 結果より，膜モデル作製のための犠牲モデルは WAX : PVA = $3: 2$ の混合比材料で作製する。

\section{2 化学的特性（溶解度）の評価}

溶解度の測定は経過時間に対する質量変化を測定することで 評価した，実験には，温度を $50^{\circ} \mathrm{C}$ 一定にした，超音波洗浄機を 用いた，また溶解溶液は PVA を非常によく溶かす DI 水, WAX を非常によく溶かすアセトン, そして今回は混合材料を用いて いるので溶液も DI 水とアセトンを $1: 1$ で混合した溶液を用意 し, 上記の三種類の溶液で溶解度評価測定実験を行った。質量 測定は, 測定ごとに溶液中から試験片を取り出し, 一定時間乾

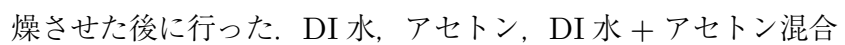
溶液に対する溶解度測定実験結果を Fig. 6 に示す. DI 水には PVA 成分がよく溶けるので, WAX + PVA 混合材料試験片も 溶かすことができた，WAX 試験片の質量変化があるのは，温 度による溶解と超音波によるエッチングの影響であると考えら 

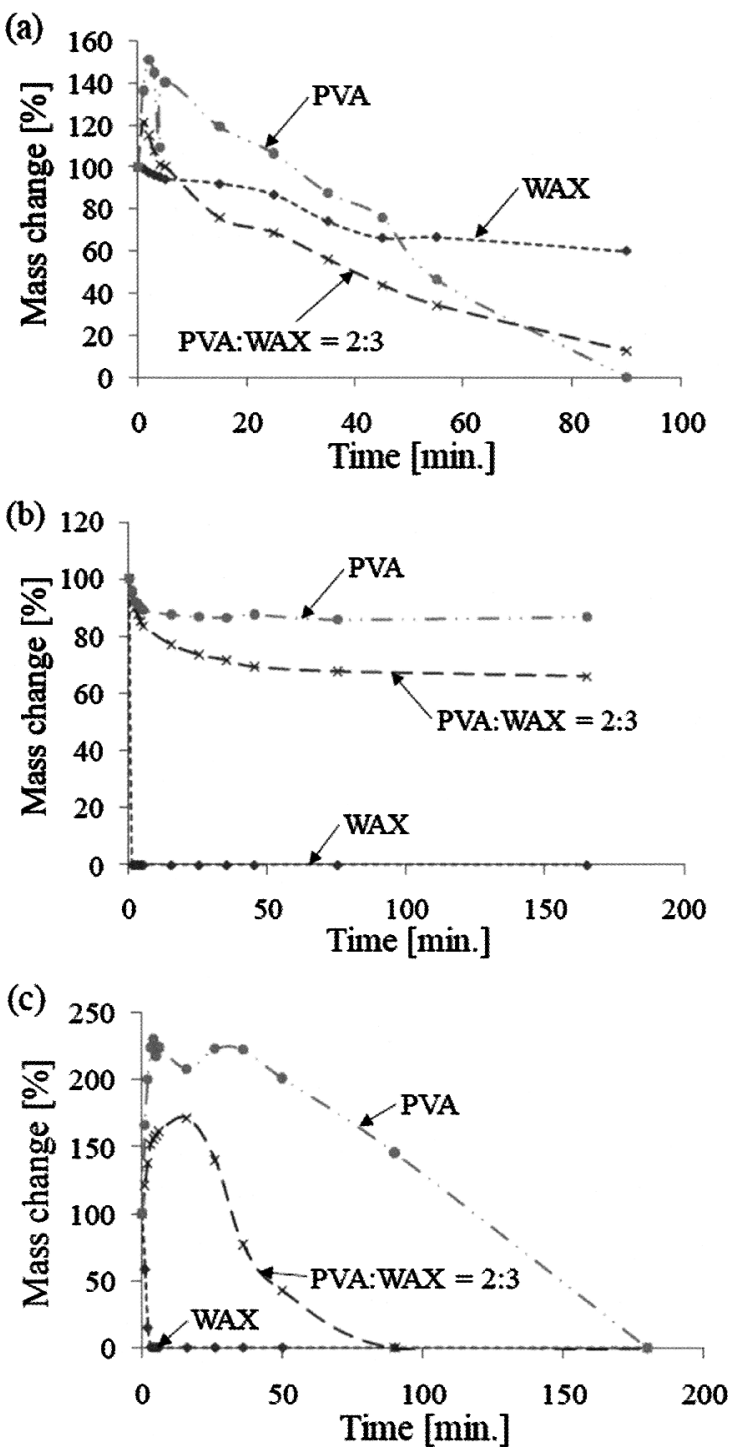

Fig. 6 Evaluation of chemical features. (a) DI water (b) acetone (c) acetone + DI water

れる。アセトンには WAX 成分がよく溶けるが，WAX + PVA 混合材料試験片の質量変化が小さいことが確認できた。これは, WAX が PVA によりコートされ，アセトンに触れていないため だと考えられる。DI水＋アセトン混合溶液には，WAX + PVA 双方の成分が溶けることが予測され，実験結果も予想どおりで あった，DI 水・アセトンそれぞれ単体の溶液の溶解速度と比較 すると，混合溶液では溶解速度は低下しているが，すべての試 験片を溶かすことができた。また，試験開始から 10 分経過後 の範囲では，DI 水が含まれている溶液中では，PVA 成分が水 分を含み膨潤し，質量が増えることも確認した．以上の結果か ら, WAX + PVA 混合材料を用いたモデルを溶解させる際は, DI 水・アセトン混合溶液が最適であると考えられる.

\section{4. 細動脈膜モデルの作製}

4.1 犠牲モデルの作製プロセス

犠牲モデルは, 外径 $500[\mu \mathrm{m}]$, 長さ $4[\mathrm{~mm}]$ で一様径 Y 字分
1. Coating a negative photoresist
on the glass substrate

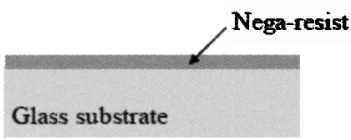

3. Development with best condition

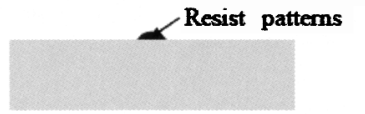

2. Exposure with best condition from backside of substrate

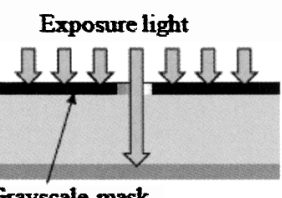

4. Transcribing the resist patterns onto PDMS

\section{PDMS substrate}

Fig. 7 Process chart of gray-scale lithography

1.Coating WAX + PVA mixture

2.Spliting superfluous mixture

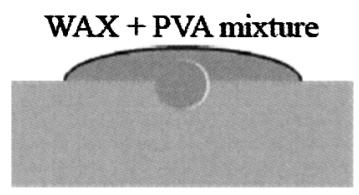

PDMS substrate

3.Drying mixture
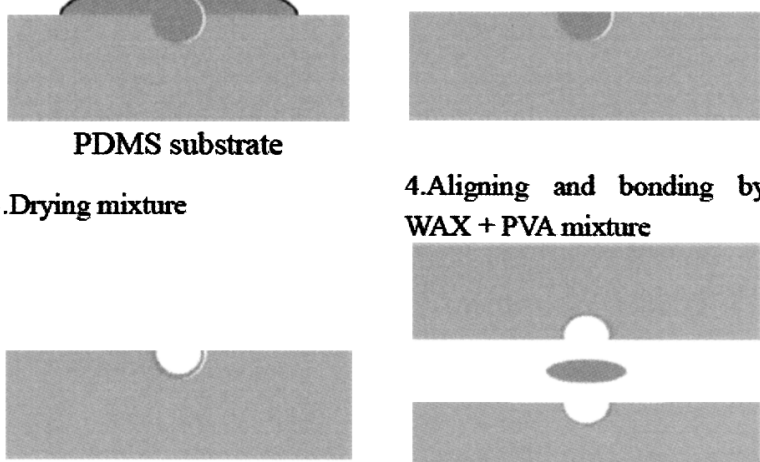

4.Aligning and bonding by WAX + PVA mixture

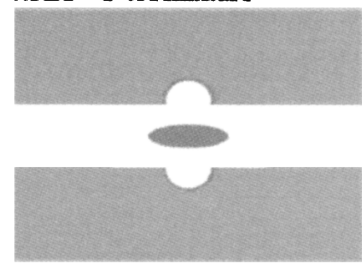

Fig. 8 Process chart for sacrificial model
岐形状を設計した。犠牲モデルはパターニングした PDMS 基 板と WAX+PVA 混合材料を用いて, 円形断面で作製する. 犠 牲モデルの型となる PDMS 基板はネガ型フォトレジストであ る KMPR をグレイスケールリソグラフィーによって球面露光 することでパターン作製し, PDMS にパターン転写することで 作製した $[13] 〜[23]$. 以下に，グレイスケールリソグラフィーを 用いた PDMS 基板のパターニング，そして犠牲モデル作製プロ セスを説明する。

·PDMS パターニングプロセス（Fig. 7).

1. ガラス基板にネガ型フォトレジスト KMPR を塗布する.

2. ガラス基板の裏側からグレイスケールマスクを用いて露 光する.

3.レジストパターンを現像する.

4. PDMS 基板にレジストパターンを転写する。

・犠牲モデル作製プロセス（Fig.8）.

1. PDMS 基板のパターン面に $\mathrm{WAX}+\mathrm{PVA}$ 混合材料を塗 り达む。

2. 余分な混合材料をすりきって，取り除く.

3. 室温で 10 分程度静置し, 水分を蒸発・乾燥させる.

4. 混合材料を塗り込んで乾燥させた PDMS 基板を二枚準備 

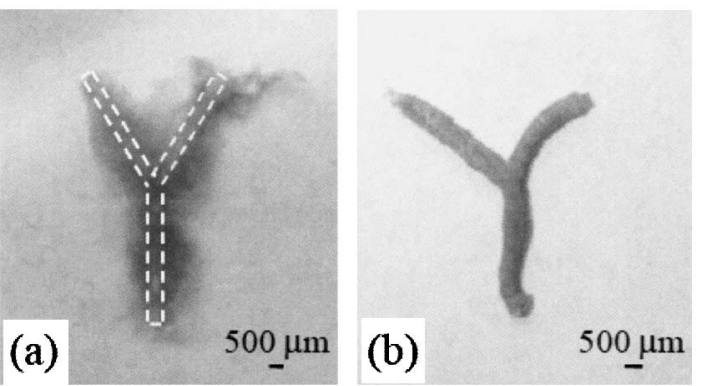

Fig. 9 Fabricated sacrificial models. (a) The sacrificial models before removing the stacking mixture. (b) The sacrificial models after removing the stacking mixture

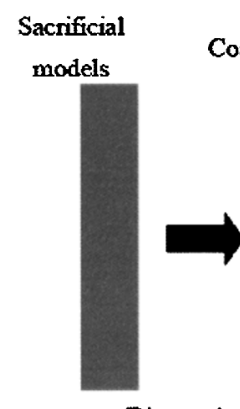

(a)

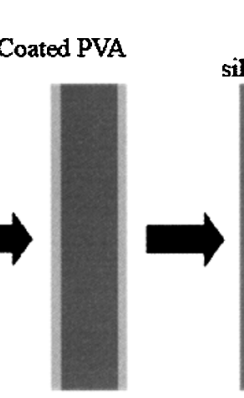

(b)
Coated

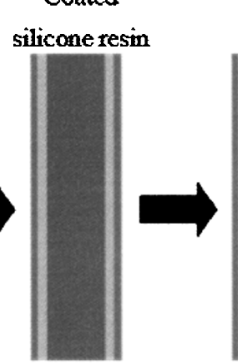

Solvent
Membrane

models

models

(b)

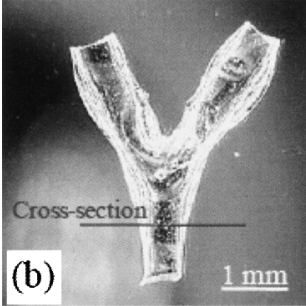

(a)

Arteriole membrane model

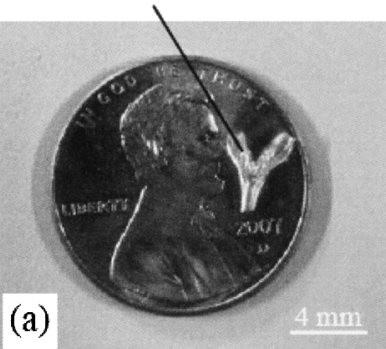

Fig. $11 \Phi 500[\mu \mathrm{m}]$ arteriole membrane model made by using WAX and PVA mixture material and grayscale lithography. (a) fabricated arteriole membrane model on a cent coin. (b) fabricated arteriole membrane model. (c) cross-section of fabricated arteriole membrane model

\section{5. 結 果・考 察}

今回, 脳底血管のような内径 $100[\mu \mathrm{m}]$ 程度の血管内で起こる 血管疾患を治療対象にできるようにするため, そして流体力学 的に血流再現性を向上させるために, 従来の血管シミュレー夕 に組み込むための内径 10～500 [ $\mu \mathrm{m}]$ の細動脈・毛細血管モデル の作製を提案し, 内径 $500[\mu \mathrm{m}]$ の Y 字分岐型細動脈膜モデル の試作と, 今回の膜モデル作製に必要な犠牲モデル作製に用い た WAX + PVA 混合材料の機械的特性 ·化学的特性の評価を 行った.

今回の細動脈膜モデルの作製において, WAX + PVA 混合材 料を犠牲モデルの作製に用いたため, 本混合材料の機械的特性 評価・化学的特性評価を行った，機械的特性評価結果から，混 合材料中の WAX の割合が上がるとヤング率が大きくなってい く傾向があることが確認された。 また, 化学的特性評価結果か ら, 溶解溶液も DI 水とアセトンを混合させた溶液が一番効果 的に WAX + PVA 混合材料を溶かすことができることを確認 した。しかし,これらの実験結果は, 試験条件やサンプルの個 体差などによる誤差や数值のばらつきを含んでいるので，今後 繰り返し試験を行うことで定量評価を行う必要がある.

細動脈膜モデル作製は, グレイスケールリソグラフィーと WAX + PVA 混合材料を用いて試作したが, 中空形状で円形度 90\%の断面を有する膜型血管モデルを作製することができた． 今回グレイスケールリソグラフィでパターニングした型は, 径 $500[\mu \mathrm{m}]$, 長さ $4[\mathrm{~mm}]$, 真円度 $89 \%$ であた. グレイスケール リソグラフィーは 100 500 [ $\mu \mathrm{m}]$ の球面パターニングで優位性 があり, 長さは $3[\mathrm{~cm}]$ 程度まで伸ばすことができるため, 複雑 分岐形状で大きなモデルを作製できる可能性がある，また，作 製した膜モデルの真円度が $90 \%$ なは，犠牲モデル作製に用い た PDMS 基板が真円度 $89 \%$ であったことによる。したがって， 
作製したモデルの真円度は妥当な結果であり, 真円度を改善す るには PDMS パターンの真円度を改善する必要がある。この ことから，グレイスケールリソグラフィーを用いたパターニン グ, WAX + PVA 混合材料を用いた犠牲モデル, そしてこれら の作製プロセスが細動脈膜モデルを作製するのに非常に有用で あったことが分かる。

謝 辞 本研究は文部科学省の科研費（17076015）㧍よび日 本学術振興会の科研費（18206027）の助成を得て行われた。

\section{参 考 文 献}

[1] L.G. Griffith et al.: "Tissue Enginering-Current Challenges and Expanding Opportunities," Science, vol.295, pp.10091014, 2002.

[2 ] R. Langer and J.P. Vacanti: "Tissue Engineering," Science, vol.260, no.5110, pp.920-926, 1993.

[ 3 ] S. Ikeda, F. Arai, T. Fukuda, M. Negoro and K. Irie: "An In Vitro Patient-Tailored Biological Model of Cerebral Artery Reproduced with Membranous Configuration for Simulating Endovascular Intervention," Journal of Robotics and Mechatronics, vol.17, no.3, pp.327-334, 2005-6.

[4] S. Ikeda, F. Arai, T. Fukuda et al.: "An In Vitro PatientTailored Model of Human Cerebral Artery for Simulating Endovascular Intervention," MICCAI 2005, LNCS 3749, pp.925$932,2005$.

[5] N. Futai, W. Gu and S. Takayama: "Rapid Prototyping of Microstructures eith Bell-Shaped Cross-Sections and Its Application to Deformation-Based Microfluidic Valves," Adv. Mater., vol.16, no.15, pp.1320-1323, 2004.

[6] B.-C. Lin and Y.-C. Su: "On-Demand Droplet Metering and Fusion Utilizing Membrane Actuation," uTAS 2008, pp.86-88, 2008.

[7] M. Ikeuchi and K. Ikuta: "The Membrane Micro Emboss (MeME) Process for Fabricating 3-D Microfluidic Device Formed from Thin Polymer Membrane," uTAS 2006, pp.693$695,2006$.

[ 8 ] J.T. Borenstein, H. Terai, K.R. King et al.: "Microfabrication Technology for Vascularized Tissue Engineering," Biomedical Microdevices, vol.4, no.3, pp.167-175, 2002.

[ 9 ] T. Nakano, Y.C. Lin, S. Ikeda et al.: "Fabrication of arteriole and capillary vessel model," The 25th Annual Conference of the Robotics Society of Japan, 3F26, 2007.

[10] T. Nakano, M. Tada, Y.C. Lin et al.: "Fabrication of celladhesion surface and Capillary Vessel Model by photolithography," International Symposium on Micro-NanoMechatronics and Human Science, Nagoya, Japan, pp.17 (1)-(6), 2007.

[11] F. Arai, T. Nakano et al.: "Fabrication of cell-adhesion surface and Arteriole Model by photolithography," Journal of Robotics and Mechatronics, vol.19, no.5, pp.535-543, 2007.

[12] T. Nakano, K. Yoshida et al.: "Fabrication of Capillary Vessel Model with Circular Cross-Section and Applications," Proc. 2008 JSME Conf. on Robotics and Mechatronics (ROBOMECH2008), 2P2-J17, 2008.

[13] K. Totsu and M. Esashi: "Gray-scale photolithography using maskless exposure system," J. Vac. Sci. Technol. B, vol.23, no.4, pp.1487-1490, 2005.

[14] K. Totsu, K. Fujishiro, S. Tanaka et al.: "Fabrication of threedimensional microstructure using maskless gray-scale lithography," Sensor and Actuators A, vol.130-131, pp.387-392, 2006.

[15] Y. Satoh, Y. Kiyosawa, T. Ishii et al.: "High Accuracy Microlens Fabrication Fethod and it's Application to LD Beam Profile Converter," Ricoh Technical Report, no.29, pp.13-20, 2003.

[16] K. Hanai, S. Shimizu and Y. Matsumoto: "Three Dimensional Structures of Negative-tone Photoresist by Binary Optics," IEEJ Trans. SM, vol.125, no.10, pp.424-425, 2005.

[17] D.A. Fletcher, K.B. Crozier, K.W. Guarini et al.: "Microfabrication Silicon Solid Immersion Lens," Journal of Microelectromechanical Systems, vol.10, no.3, pp.450-459, 2001.

[18] L. Erdmann and D. Efferenn: "Technique for monolitic fabrication of silicon microlenses with salectable rim angles," Society of Photo-Optics Instrumentation Engineers, vol.36, no.4, pp.1094-1098, 1997.

[19] S. Kang: "Replication Technology for Micro/Nano Optical Components," Japanese Journal of Applied Physics, vol.43, no.8B, pp.5706-5716, 2004.

[20] W. Yu and X.-C. Yuan: "Fabricatoin of multilevel structures in self-development photosensitive hybrid sol-gel glass by a gray scale mask," Society of Photo-Optics Instrumentation Engineers, vol.42, no.12, pp.3411-3412, 2003.

[21] M-H. Wu, C. Park and G.M. Whitesides: "Fabrication of Arrays of Microlenses with Controlled Profiles Using Gray-Scale Microlens Projection Photolithography," Langmuir, vol.18, pp.9312-9318, 2002.

[22] C. Chen, D. Hirdes and A. Folch: "Gray-Scale photolithography using microfluidic photomasks," PNAS, vol.100, no.4, pp.1499-1504, 2003.

[23] H. Wu, T.W. Odom and G.M. Whitesides: "Reduction Photolithography using Microlens Arrays: Application in Gray Scale Photolithography," Analytical Chemistry, vol.74, no.14, pp.3267-3273, 2002. 


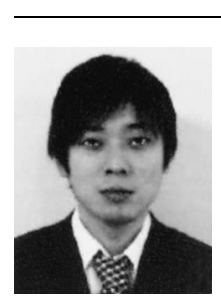

中野琢磨 (Takuma Nakano)

2008 年東北大学大学院修士課程修了. 現在, 同大 学大学院博士課程学生. 日本学術振興会特別研究員. 日本機械学会会員。（日本ロボット学会学生会員）

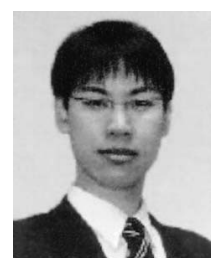

池田誠一（Seiichi Ikeda）

2006 年, 名古屋大学大学院博士課程修了. 博士 (工 学). 2006 年東北大学大学院研究支援者. 2007 年 名古屋大学大学院研究支援者. 日本機械学会会員.

（日本ロボット学会正会員）

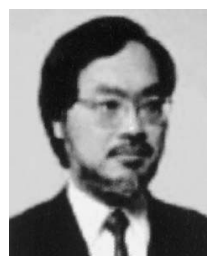

\section{福田敏男 (Toshio Fukuda)}

1977 年東京大学大学院博士課程修了, 工学博士. 同 年通産省工業技術院機械技術研究所研究員, 主任研 究官を経て, 1982 年より東京理科大学工学部機械 工学科講師, 1983 年同大学助教授, 1979 1981 年 西ドイツシュツットガルト大学客員研究員, 1986 年アメリカエール大学客員助教授，1989 年名古屋 大学工学部機械工学第 2 学科教授. 1992 年同大学機械情報システム 工学科教授. 1994 年同大学大学院工学研究科マイクロシステム工学 専攻教授 2004 年同大学大学院工学研究科マイクロ・ナノシステム工 学専攻教授, 現在に至る. 自己組織化ロボット, マイクロロボット, マイクロ・ナノマニピュレーション, インテリジェント制御, ロボッ トハンドやマニピュレータの制御, 特殊環境下のロボットの研究等に 従事.

（日本ロボット学会正会員）

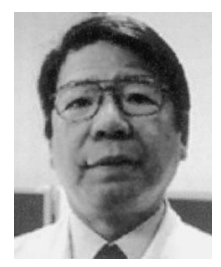

根来 真 (Makoto Negoro)

1973 年ハーバード・メディカル・スクール, ベス. イスラエル病院, 神経外科研究フェロー.1980 年 名古屋大学大学院医学部助教授. 2002 年藤田保険 衛生大学医学部神経外科教授, 現在に至る.

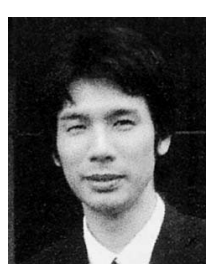

吉田圭佑（Keisuke Yoshida）

2009 年東北大学卒業. 2009 年東北大学大学院修士 課程入学, 現在に至る.

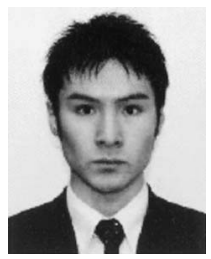

大浦裕就 (Hiroyuki Oura)

2009 年名古屋大学大学院修士課程修了. 日本機械 学会会員

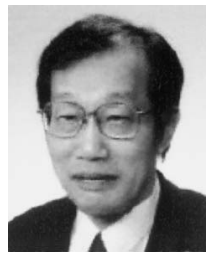

松田武久 (Takehisa Matsuda)

1972 年京都大学大学院博士課程修了. 工学博士 1972 1974 年 Case Western Reserve University にて研究員. 1980～1998 年循環器病センター研究 所にて生物工学部門長. 1998 2006 年九州大学大 学院医学研究科名誉教授, 現在に至る.

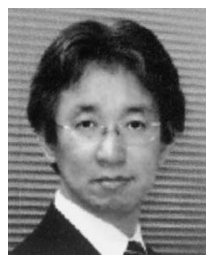

新井史人（Fumihito Arai）

1988 年東京理科大学大学院修士課程修了. 1989 年 名古屋大学工学部助手, 1993 年工学博士 (名古屋 大学), 1994 年講師, 1998 年助教授. 2005 年東 北大学大学院工学研究科バイオロボティクス専攻 教授，現在に至る。 2000 年 IEEE，RAS, Early Academic Career Award, 2004 年日本ロボット学 会論文賞など受賞. マイクロ・ナノロボット工学, バイオ・メディカ ルシステム等の研究に従事.

（日本ロボット学会正会員） 